\title{
Expert Views on Strategies in Ensuring Effectiveness of Housing Planning and Control Activities
}

\author{
Hamizah Yakob, Fatimah Yusof, Hazlina Hamdan \\ Faculty of Architecture, Planning and Surveying, \\ Universitl Teknologi MARA, Shah Alam, Malaysia \\ hamizah1204@gmail.com
}

\begin{abstract}
The weaknesses and ineffectiveness of the planning mechanism involved in the preparation of development plans and its implementation through development control have significantly given impact to the housing production process. The objective of this paper is to explore strategies for facilitating the effectiveness of the implementation of housing planning and control among decision makers and implementers in housing development. This in-depth interview is aimed to explore their strategies or plan of actions for ensuring the effectiveness of planning activities. It was found that the strategies can be classified into two stages; the preparation stage and implementation stage.
\end{abstract}

Keywords: Development Plan; Planning Control; Urban Housing Development

eISSN 2398-4295 @ 2018. The Authors. Published for AMER ABRA cE-Bs by e-International Publishing House, Ltd., UK. This is an open-access article under the CC BY-NC-ND license (http://creativecommons.org/licenses/by$n c-n d / 4.0 /$ ). Peer-review under responsibility of AMER (Association of Malaysian Environment-Behaviour Researchers), ABRA (Association of Behavioural Researchers on Asians) and cE-Bs (Centre for EnvironmentBehaviour Studies), Faculty of Architecture, Planning \& Surveying, Universiti Teknologi MARA, Malaysia.

DOI: http://dx.doi.org/10.21834/ajbes.v3i13.144 


\subsection{Introduction}

In Malaysia, the current planning mechanisms are recognised as important tools in the housing planning process, especially in urban areas. It is possible for town planning to impose constraints on housing development through development plan by which the land is identified for future development together with development policies on intensity, designs and land use zoning. In addition, through development control, the local planning authority set procedures to be followed, processing requirements, planning standards and guidelines, and duration of its activities as to preserve, control and protect the environment. The issues concerning the development control process include delay of planning approvals, lack of consistency in decision making, the poor content of the development plans and lack of manpower resources.

The weaknesses and ineffectiveness of the planning system in the preparation of development plans (Dola, 2009; Rameli, 2009,2011; Ahmad, 2011) and its implementation through development control mainly during housing application and approval (Yakob, 2012) have significantly given impact to the housing production process. Thus, the objective of this paper is to explore strategies for facilitating the effectiveness of implementation of housing planning and control among decision makers and implementers in housing development. It is aimed to explore their strategies or plan of actions for ensuring the effectiveness of planning activities such as policy formulation, land location and size determination of housing development, as well as housing application procedures. The literature review below discusses the issues highlighted in in-depth interviews as the continuation of findings from a questionnaire survey.

\subsection{Literature Review}

The planners viewed the current practices of housing planning in the study area as weak and ineffective based on certain highlighted aspects. They postulate that the existence of housing problems in Selangor occurred due to the weaknesses and the ineffectiveness of the housing planning process, starting from the formulation of policy stage to the planning control stage. Regarding policies, there are loopholes in the formulation of policy due to several aspects such as market fluctuation, unavailability of data to monitor the implementation of policies (Rameli, 2009; Mohd, 2011; Foo et al, 2014), poor computerised systems that link the applications submitted and existing housing developments (Chua \& Deguchi, 2008), time taken for Local Plan (LP) reviews (Yakob, 2012), lack of experience among officers (Yakob, 2013; Monkkonen, 2013), no study on income projections and lack of housing market consideration during feasibility studies (Rameli et al, 2011; Dunse, 2013).

Meanwhile, in terms of development strategies, most planners perceived that consideration of economic factors in determining land location, especially in terms of housing demand, has been given less attention. This consequently generates housing zones which do not reflect the actual demand (Jae, 2011; Gurran et al, 2011). They also pointed out errors in the calculation of population projection, which results in surplus and shortages. Other factors of oversupply highlighted by the respondents are poor implementation and enforcement (Othman,2006), locational disadvantages (Rameli, 2007; Mohd et al, 2009; Lin, 
2012), unaffordable price of the houses (Burgress, 2010; Bakhtiyar, 2013),over planning and land expansion.

Furthermore, in relation to land size, it was claimed that there are no actual data on the types of houses based on income patterns of people who are in need of housing. In addition, they also pointed out that there are loopholes in planning guidelines for housing development, especially within the provision of community facilities and open space (Maliene et al, 2005; Mohd et al, 2007; Mohit et al, 2010; Ismail et al, 2015). It was claimed that the problems are much related to the size and quantity required for facilities and open space provisions within the housing areas. This is due to the increased land value and limited access to land supply.

In terms of planning control process, they perceived that the level of compliance is low for aspects of low cost housing $(\mathrm{LCH})$ policies and housing category especially for $\mathrm{LCH}$ and medium-low cost housing (MLCH). Among the factors leading to non- compliance are weaknesses in the preparation of the structure plan (SP) and LP (Yakob, 2015), not enough understanding of zoning and laws, prolonged period of plan reviews which lead to outdated content, lack of integrity among officers and the pressures of development (Osman et al, 2014). Regarding the factor of difficulty during the planning control process, they perceived that waiting time (Ball, 2011) is the most difficult, especially when it comes to water supply requirements in the study area. Political influences have caused difficulty in getting approvals (Ahmad, 2013). They also perceived that in some cases, bribery is encouraged due to the issues of delays. Table 1 shows a summary of issues and problems raised and highlighted during an in-depth interview leading to recommendation of strategies to improve housing planning and control in urban housing developments.

Table 1. Summary on Issues and Problems highlighted in an In-Depth Interview that Leading to Recommendation of Strategies to Improve Urban Housing Planning and Control

Issues in Housing Problems
Planning and Control

Activities

Policies

Market fluctuation, unavailability of data to monitor the implementation of policies, poor computerised system, time taken for LP reviews, lack of experience among officers, no study on income projections, lack of housing market consideration during the feasibility study

Land Location Errors in calculation of population, housing zones that do not reflect the actual demand; no synchronization between LPA's boundary.

Land Size No actual data on the types of houses based on income pattern, loopholes in planning guidelines in terms of size and quantity of open space and facilities; Land expansion leading to urban sprawl

Non-Compliance Weaknesses in the preparation of SP and LP, not enough understanding of zoning and laws, prolonged period for plan reviews which lead to outdated content; lack of integrity among officers and the pressures of development.

Factor of Difficulties Political influences, Waiting times for review letter; Encouraging bribery due to delay; OSC 3.0 is cumbersome

$Q=$ How to streamline and strengthen the planning and control activities in urban housing development?

(Based on the issues and problems highlighted above during interview survey) -FOCUS OF THE STUDY- 


\subsection{Methodology}

The study is conducted through a face-to-face expert interview approach with the government planners and planning consultants in Selangor as a sample. In order to select appropriate respondents, the purposive sampling technique was applied by choosing respondents based on their years of experience of more than ten (10) years and also their involvement in the preparation of development plans, housing layout plans, submission and approval of housing planning applications. A total of fifteen respondents $(n=15)$ was selected and interviewed which includes a State Deputy Director, divisional heads of Federal Town and Country Planning Department $(n=2)$, an employee of Lembaga Perumahan Dan Hartanah Selangor $(n=1)$, and Assistant Directors from local planning authorities (LPAs) $(n=2)$. They hold professional managerial positions with Gred J48 and above. The remaining respondents are private town planners holding the positions of Principals of town planning $(n=8)$ and Assistant Principal $(n=1)$ of consultant firms. They are also corporate members of the Malaysian Institute of Planners (MIP). These respondents were identified after analysing the data from the respondent's profile collected during the questionnaire survey. In analysing the data, government planners were coded as $\mathrm{G} 10$ to $\mathrm{G} 15$ and planning consultants as $\mathrm{P} 1$ to P9.

The process of interview was undertaken during the span of two and a half months, from 10 July to 20 September 2014. A list of predetermined questions was developed to be asked to the respondents face-to-face. It comprised of seven (7) main questions which attempted to gain insight on the issues and problems as well as to uncover the reasons behind the current practices of housing planning and control in the study area. Questions highlighted were; 1) loopholes in the policy for housing, 2) advantages and disadvantages of the new policy "Rumah Selangorku", 3) Factor of land location, 4) Factor of land size, 5) Factor of non-compliance with planning requirements, 6) Factor of difficulties during housing approval process, and 7) Suggestions to improve the housing planning and control system. However, this paper only discusses question no. 7, which was based on issues and problems raised in question 1 to 6 . Each session took approximately 60 to 90 minutes, depending on respondents' interest and was video and audio recorded. However, this study has its limitation. Rambling sometimes occurs when the interviewee moves away from the chosen areas that the researcher had in mind. During the interviews, although the questions were properly posed by researchers, there was a tendency among the respondents to not properly answer the questions but instead elaborate on certain aspects which were out of the scope of the questions. Therefore, in some cases, the researcher had to guide respondents and propose several answers to avoid bias in terms of response accuracy. In addition, unnecessary answers were omitted during the analysis.

Atlas.ti software was used in this study to find deeper meaning and connections within the interview transcripts by mining for themes, similarities and differences (Friese, 2012). All responses were coded as lean coding using an Atlas.ti software. Lean coding was derived from variables or concepts in the study, namely policy, land location, land size, guidelines and housing application and approvals as well as recommendations. Each variable was coded into several categories (families) which answer the research questions and its objectives. The transcript files were assigned and imported into a new "Hermeneutic Units" 
$(\mathrm{HU})$ or a project in the software. The HU editor then shows the content of all data files and the quotations were coded in accordance with suitable coding items derived from the research questions. The number of items for each coding were then identified and categorised from the list of quotations. As output, network mapping (relationships) was used to build theoretical models which are defined by a set of nodes and links within Atlas.ti (refer Appendix). The software does not write the report, but helps in narrating components by providing visual representations and readily available quotes to be incorporated in the report (Ducharme, 2014).

\subsection{Results and Discussion}

Based on the result from Atlas.ti, there are seventeen (17) items (based on lean coding), thirteen (13) quotations from government planners (respondent G10 to G15) and forty five (45) quotations from planning consultants (respondent P1 to P9) as output included in the network mapping. Figure 1 shows the network mapping with the number of items and quotations relating to suggestions and recommendations from the in-depth interviews (Appendix). However, only selected quotations were used in this paper for discussion.

There are several suggestions and recommendations for improvement in the current practice of housing planning and control as highlighted by the respondents. The suggestions refer to the question of "How to streamline and strengthen the planning and control in urban housing development?". Findings indicated that suggestions from respondents fall within into two (2) categories; during the preparation stage and during the implementation stage. In this case, the implementation stage points towards the roles of the Federal government, State government and Local Planning Authorities (LPAs) (Table 2).

\subsection{During preparation stage}

- More involvement of developers

It was suggested that more involvement of developers is encouraged during the preparation of Structure Plans and Local Plans (SP and LP). In addition, it was pointed out that the developer could give a clear picture of housing development based on market feasibility studies. This method of Focus Group Discussion (FGD) is practiced in certain States including Selangor. However, it was claimed that the increased participation among housing developers could improve future housing development and market (demand and supply).

- Plan for redevelopment of old areas

There was also argument regarding the effectiveness of housing policy formulation in the preparation of SP fulfilling future housing needs. Therefore, in order to enhance effectiveness, the Federal government needs to focus on redevelopment of old areas rather than concentrating on developing housing within new areas mainly in urban areas. With limited supply of land plus its increased value, redevelopment of old areas is the best way to include more supply of housing in urban areas. 
Yakob, H., et.al. / Asian Journal of Behavioural Studies (AjBeS), 3(13) Sep / Oct 2018 (p.68-77)
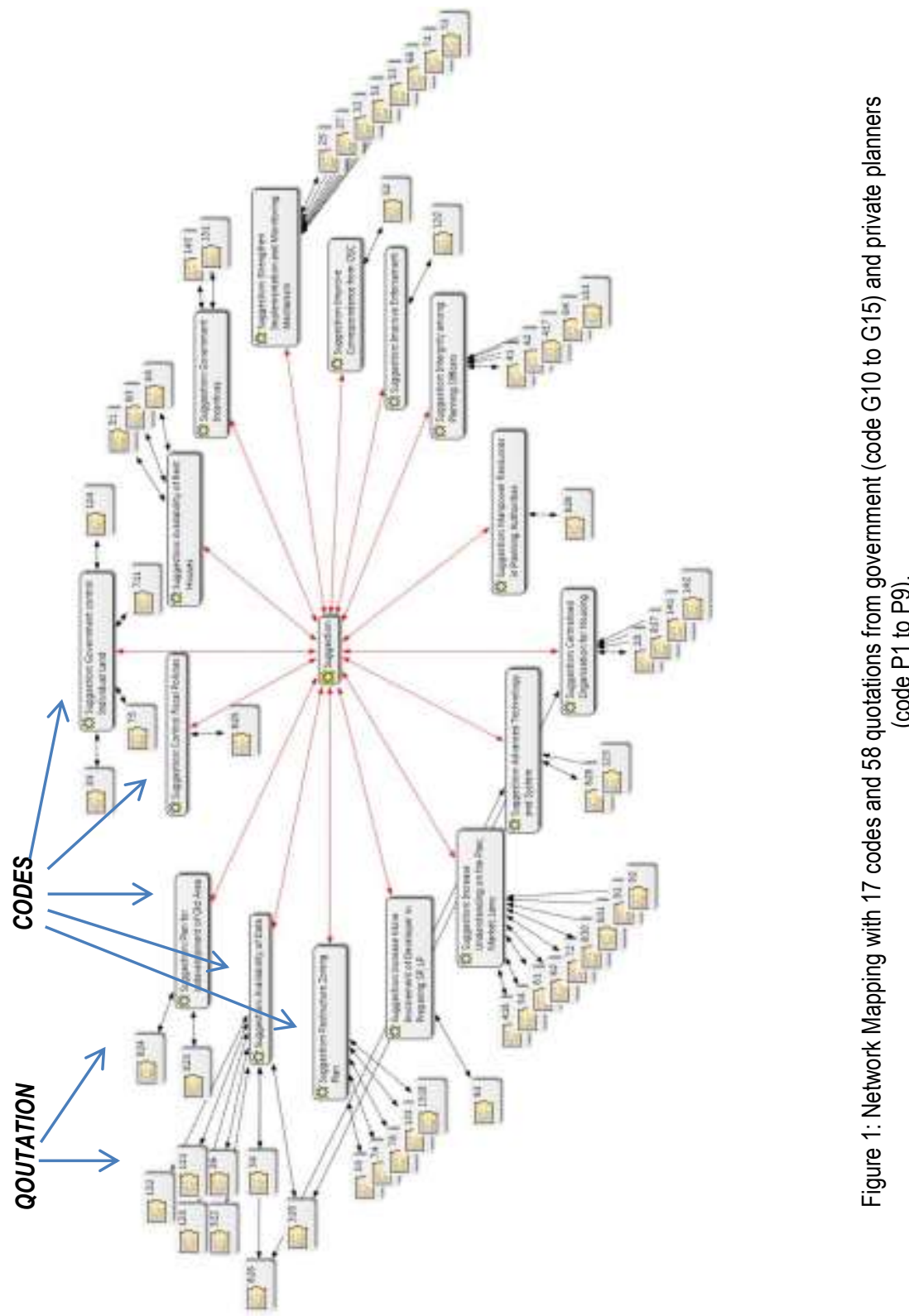
- Restructuring the zoning plan

It was also suggested that the zoning plan should be restructured during preparation of development plans. Among the aspects highlighted by the respondents is, zoning should specify the types of housing for certain areas in the plan e.g. based on the Planning Blocks (PB). This could guide any housing development within the area rather than zoning for housing land use while the type of housing is decided later during a housing application stage. In addition, it was highlighted that planners should include priority development areas and types of housing rather than focussing on zoning for housing only. Also, zoning of housing could be classified into three categories as practiced in developed countries. By revisiting zoning procedures, it was claimed that the preparation of the LP will become much easier and the area could be more specific.

- Increased understanding of plans, laws and market study

The understanding of the plans, laws and market study should be increased among those involved in housing planning and control. It was suggested that the Development Proposal Report (DPR) needs to be intensified because only planners have the authority and skills in its provision.

- Availability of data

To fulfil all recommendations highlighted previously, the actual data should be available and complete in order to guide planners in the process of planning and control. Data such as existing housing stocks and units, number of applications approved, the number of units that have been developed, committed development, housing types, current housing market prices and housing demand should be available and easy to access.

\subsection{During implementation stage}

- Improve and increase use of advanced technology and system within LPAs

In order to control the housing supply, especially in meeting housing needs and targets, it is necessary for every LPAs to set up a computerised system that links to the number of housing applications submitted and existing units that have been built. In addition, with a centralised control system, cooperation among departments within the LPAs can be improved in terms of sharing information on housing development projects.

- Increase manpower resources in planning control process and improve One Stop Centre (OSC)

Regarding the issue of monitoring, increased manpower resources are necessary within the LPAs. It was suggested that the government should increase the number of positions in charge of monitoring the land, submitted applications and development growth. This could also improve correspondence time in the OSC where each technical department becomes more responsive and the plan will be approved in a timely manner. In addition, it is important to foster integrity among planning officers and their attitudes during the planning control process.

- Improve enforcement and monitoring system

Planners should take responsibility in ensuring the effectiveness of policy and strategy implementation through monitoring and enforcement. It was suggested that weekly 
monitoring by the LPAs should be practiced in regards to how many units are to be developed, along with the approved plan.

- Provision of government incentives and subsidies

Policies related to housing should provide incentives or subsidies for developers who implement the policy in terms of tax reduction. The tax reduction could be applied for any new approaches introduced by the government or implementation of planning guidelines and design standards for housing.

- Controlled land by government

Regarding development phasing issues, it was suggested that individual land should be controlled by the LPAs as practiced by the Housing Development Board (HDB) in Singapore and Hong Kong. All individual lands were converted into government land in order to control ownership. They control ownership through the allocation of 1 room for single persons, 2 rooms for young married couples and they can later move to larger houses when their income increases.

- Controlled fiscal policies by the government

The government should control fiscal policies as it was argued that the control of housing stock and supply is not through the numbers specified by the SP and LP, but from Bank Negara fiscal policies. However, there are more stringent policies when housing oversupply takes place. Therefore, strengthening the process of planning through the control of the housing supply depends on stringency of loan approvals for housing development projects.

\subsection{Conclusion}

The result of this study's analysis suggests that several major steps are needed in order to ensure effectiveness of implementation in housing planning and control process to push towards success in urban housing development and promote better living environments. The analysis indicates economic factors should be considered during the preparation of SP and LP especially in terms of demand and price of houses that people can afford. This is important in housing forecast to portray the actual requirements of future housing in certain areas, other than the total quantity of housing needs. The analysis also indicates the formulation of specific policies that enable the LPAs to consider the housing market and study on income projections in the process of housing approval. Additionally, the consideration of housing market demands in determining location for future housing development is very appropriate and rational.

Regarding the causes of failure in the distribution of the housing land area, the analysis indicates that there are many contributing factors and justifications. The main causes are the influence and interference of politicians, lack of income study, poor implementation, zoning not reflecting the actual demand and zoning not taking into account the amount of land acquired. In relation to non-compliance, there are suggestions highlighted such as improvement of planning control in terms of enforcement and monitoring mechanisms, increasing the level of knowledge and integrity among those involved in approvals. Furthermore, it was perceived that the problem of waiting time could be improved through 
the use of advanced technology and system in LPAs. The increase in manpower resources for monitoring implementation will improve and strengthen enforcement.

The outcomes of this paper are expected to guide future researchers in exploring housing planning activities and process in detail. In addition, the weaknesses that were identified, together with the recommendations to improve the process of housing planning and activities could serve as a guide for town planners, LPAs as well as state authorities to properly plan, control and approve future housing supply. However, it should also be noted that this research requires continuous assessment by identifying and ranking the significant factors which contribute to the issue of ineffectiveness in housing planning and control activities. This may not be limited to the perspective of town planners, but may be approached from the perspective of other stakeholders such as housing developers, property analysts and house buyers.

\section{Acknowledgement}

This research is funded by the Ministry of Education, Malaysia and Universiti Teknologi MARA. Also, special thanks to the respective respondents for their cooperation in participating in this in-depth interview survey.

\section{References}

Ahmad, F., Mohd, I., Maidin, S.L., Zainol, R., \& Mohd Noor, N. (2013). Malaysian development plan system: Issues and problems, one decade after its reform (2001-2011). Journal of Malaysian Institute of Planners, 11, 1-20.

Bakhtyar, B., Zaharim, A., Sopian, K., \& Moghimi, S. (2013). Housing for poor people: a review on low- cost housing process in Malaysia.WSEAS Transactions on Environment and Development, 9, 126-136.

Ball, M. (2011). Planning delay and the responsiveness of English housing supply. Urban Studies.48 (2), 349 -362.

Burgess, G,.Monk, S. \& Whitehead, C. (2010). How can the planning system deliver more housing?. Joseph Rowntree Foundation. 1-8.

Chua, R.S., \& Deguchi, A. (2008). Implementation issues on planning control according to the provision of Town and Country Planning Act 1976 in Malaysia. Journal of Architecture and Urban Design,14, 47-58

Dunse, N., Thanos, S. \& Bramley, G. (2013). Planning policy, housing density and consumer preferences. Journal of Property Research.30 (3), $221-238$.

Foo, L. H.R., \& Wong, C. (2014). Planning for housing development in Malaysia: developers' response to the regulatory policy framework. International Planning Studies. 19 (2). 192- 209.

Gurran, N., Gilbert, C. \& Phibbs, P. (2013). Planning and the housing market: measuring regulatory difference and implications for explaining supply and affordability trends. $7^{\text {th }}$ Australasian Housing Researchers' Conference. $6^{\text {th }}$. $8^{\text {th }}$ February 2013.

Gurran, N., \& Whitehead, C. (2011). Planning and affordable housing in Australia and the UK: a comparative perspective. Housing Studies. 26 (7-8), 1193- 1214. 
Ismail, W \& Said, I. (2015). Integrating the community in urban design and planning of public spaces: a review in Malaysian cities. Procedia-Social and Behavioural Sciences, 168, 357-364.

Jae, H.K. (2011). Linking land use planning and regulation to economic development: a literature review. Journal of Planning Literature. 26 (1). 35-47.

Maliene, V. \& Malys, N. (2009). High- quality housing- a key issue in delivering sustainable communities. Building and Environment Journal. 44 (2). 426-430.

Mohd, I, Ahmad, F. \& Aziz, WA. (2009). Exploiting town planning factors in land development: case study of urban housing in Kuala Lumpur, Malaysia. Journal of Facilities Management. 7 (4), 307 - 318.

Mohd, I, Arby, E. \& Ramly, A. (2007). Urban housing development: town planning issues. Journal of Malaysian Institute of Planners, 43-59.

Mohd, T. \& Alias, G. (2011). The role of housing planning practices in contributing towards housing oversupply. World Academy of Science, Engineering and Technology. 59. 767-775.

Mohit, M., Ibrahim, M. \& Rashid, Y.R. (2010). Assessment of residential satisfaction in newly designed public lowcost housing in Kuala Lumpur, Malaysia. Habitat International. 34 (1). 18-27.

Monkkonen, P. (2013). Urban land use regulations and housing markets in developing countries: evidence from Indonesia on the importance of enforcement. Land Use Policy Journal. 34. 255-264

Osman, M, Bachok, S, Bakri, N.I, \& Harun, N. (2014). Government delivery system: effectiveness of local authorities in Perak, Malaysia. Procedia Social and Behavioural Sciences. 153. 452-462.

Othman, A. (2006). Developer's strategies in dealing with planning control: its impact on the urban housing development. Malaysian Journal of Real Estate. 1(2). 7-15.

Rameli. A. (2007). Application of method of content analysis and perception survey in evaluating the effectiveness of planning system in managing housing supply. Proceedings of the $2^{\text {nd }}$ Post Graduate Seminar on Research of Built Environment 2007. March 6. Faculty of Built Environment. Universiti Teknologi Malaysia.

Rameli. A. (2009). Land use planning system and housing development. Ph.D. Thesis. UTM, Malaysia

Rameli, A. \& Aman, R. (2011). Ineffectiveness of planning control and its implications to housing oversupply. Journal of Civil Engineering and Architecture. 1-15

Yakob, H., Yusof, F., \& Hamdan, H. (2012). Land use regulations towards sustainable urban housing: Klang Valley conurbation. Procedia Social and Behavioural Sciencess, 68, 578-589

Yakob, H., Yusof, F., \& Hamdan, H. (2013). Sustainable Urban Housing Development through Planning Mechanism: Issues and Challenges. Asia Pacific Network for Housing Reseach (APNHR) Proceedings

Yakob, H., Yusof, F., \& Hamdan, H. (2015).Stakeholders' perception on effectiveness of housing planning and control in urban areas: a preliminary survey. Procedia Social and Behavioural Sciences, 168, 289-301. 